\section{Tubular Factors in the Development of Extra-renal Azotæmia}

Ir is well known that in the mechanism of extrarenal azotæmia the causative factor is the loss of sodium and subsequent dehydration'. According to Gömöri and co-workers ${ }^{2}$, the causes of dehydrationazotæmia are as follows: (1) blood pressure falls, and in consequence of the dehydration the colloidoncotic pressure of the blood plasma increases, thus resulting in a drop of the glomerular filtration-rate; (2) circulation is slowing down, contributing thus to the diminished filtration-rate; (3) excessive rotein catabolism helps to aggravate the uræmic condition.

Some clinical observations, and the fact that during dehydration the concentrating power of the kidneys decreases, led us to investigate the role of the tubules during this condition.

Dehydration was developed in rabbits, by Darrow and Yannet's technique ${ }^{3}$, of infusion to, and subsequent withdrawal of, an isotonic dextrose solution from the peritoneal cavity. Our results show clearly that: (1) in dehydration there is a significant decrease of the endogenous creatinin clearance (glomerular filtration-rate), but a still greater decrease of the urea clearance; in the control period, the ratio urea clearance/creatinin clearance was $0 \cdot 68-0.87$, whereas during dehydration it was $0 \cdot 07-0 \cdot 20 ;(2)$ this must be due to enhanced tubular re-absorption of urea; normally $20-40$ per cent of the filtered urea was re-absorbed, but during dehydration it was as much $\varepsilon s 80-90$ per cent.

Thus it seems to be beyond doubt that in the development of dehydration-azotæmia, besides the hæmodynamic glomerular factors, a tubular factor plays its part too. The cause of the increased re-absorption of urea may be found in various factors. The known diffusibility of urea renders it especially liable to passive re diffusion. But it seems to be certain that the histological changes in the kidneys of dehydrated animals (Gömöri and Romhányi's ${ }^{4}$ findings of medullary hyperæmia and tubular lesions in dehydration) make the tubules especially suited for re-diffusion. These histological changes were found in our experiments also.

\begin{tabular}{|c|c|c|c|c|c|c|c|}
\hline \multirow{2}{*}{ Period } & \multirow{2}{*}{$\begin{array}{c}\text { In- } \\
\text { terval } \\
\text { (min.) }\end{array}$} & \multirow{2}{*}{$\begin{array}{c}\text { Urine } \\
\text { flow } \\
\text { (ml./ } \\
\text { min.) }\end{array}$} & \multicolumn{2}{|c|}{ Creatinin } & \multirow{2}{*}{$\begin{array}{l}\text { Urea } \\
\text { clear. }\end{array}$} & Urea clear. & \multirow{2}{*}{$\begin{array}{c}\text { Serum } \\
\text { NPN } \\
(\mathrm{mgm} \\
\%)\end{array}$} \\
\hline & & & $\mathrm{U} / \mathrm{P}$ & Clear. & & Creatinin clear. & \\
\hline $\begin{array}{l}1 \\
2 \\
3 \\
4 \\
5 \\
6 \\
7\end{array}$ & $\begin{array}{r}225 \\
524 \\
1429 \\
1964 \\
2934 \\
3390 \\
4319\end{array}$ & $\begin{array}{l}0.178 \\
0 \cdot 136 \\
0 \cdot 031 \\
0 \cdot 045 \\
0 \cdot 007 \\
0 \cdot 091 \\
0 \cdot 131\end{array}$ & $\begin{array}{l}73 \\
33 \\
96 \\
16 \\
17 \\
12 \\
19\end{array}$ & $\begin{array}{c}13 \cdot 0 \\
4 \cdot 5 \\
3 \cdot 0 \\
0 \cdot 7 \\
0 \cdot 12 \\
1 \cdot 1 \\
2 \cdot 5\end{array}$ & $\begin{array}{l}8 \cdot 8 \\
1.8 \\
0 \cdot 30 \\
0.07 \\
0 \cdot 008 \\
0.22 \\
0 \cdot 45\end{array}$ & $\begin{array}{l}0.68^{*} \\
0 \cdot 40 \\
0 \cdot 10 \\
0 \cdot 10 \\
0.07 \\
0 \cdot 20 \dagger \\
0.18\end{array}$ & $\begin{array}{r}26 \\
40 \\
64 \\
90 \\
110 \\
144 \\
164\end{array}$ \\
\hline
\end{tabular}

* Before treatment. † Partial re-hydration with water.

In the table we give the results of one of our typical experiments. The ratio of urea to creatinin, expressing the tubular water re-absorption, emphasizes that the tubular re-absorption of urea is independent of the changes in water re-absorption, as well as being independent of the rate of urine flow.

P. GÖMÖRI

P. BÁLINT

I. Medical Clinic,

L. HÁRSING

University, Bu apest. Oct. 2.

' Kerpel-Fronius, Ed., Erg. Inn. Med., 51, 624 (1936).

- Gromöri, P., and co-workers, Acta med. Scand., 92, 347, 515 (1937) ;

102, 591 (1939); Z. ges. exp. Med., 104, $2 \%$ (1938).

${ }^{3}$ Darrow, D. C., and Yannet, H., Amer. J. Dis. Child., 46, 253 (1933).

- Gơmöri, P., and Romhányi, G., Orvosi Hetilap, 89, 21, 336 (1948) (in Hungarian).

\section{Effects of a Serum Injection after an Anti- Histaminic-Inhibited Shock}

Pasteur, Vallery Radot, Halpen and Haltzer assert that an anti-histaminic-inhibited shock has no tachiphylactic action; more precisely, rabbits pro. tected from a shock by an anti-hystaminic died of shock after another dose of serum was administered some days later. They considered the results as an argument in favour of their theory, namely, that antihistaminics prevent antigen-antibody reactions and thus leave the tissues free from antibodies to react with a subsequent dose of antigen. We have obtained contrary results, however, in analogous experiments. Thirteen guinea pigs have been sensitized with $1 / 10$ c.c. of horse serum by intraperitoneal injection. After fifteen days they were given 1 c.c. of the same serum by intracardiac injection. Eleven were given $5 \mathrm{mgm}$. of an anti-histaminic ('Dimetina', kindly furnished by Le Petit Co.) by intraperitoneal injection $10 \mathrm{~min}$. before the shock treatment. All of them survived, whereas the other two died.

These eleven guinea pigs were given next day another shock treatment with 1 c.c. of the same serum treatment by intracardiac injection. All of them survived. The weight of each guinea pig was about $300 \mathrm{gm}$.

Thus it seems that the anti-hystaminics do not inhibit the antigen-antibody reaction, and the latter disappears after an anti-histaminic-inbibited shock. This fact may be of considerable therapeutical value.

Vincenzo Traina

Clinica Pediatrica, Pavia.

${ }^{3}$ C.R. Soc. Biol. (March 1947).

\section{Folic Acid as an Anti-anaphylactic}

TEN guinea pigs (of medium weight, $350 \mathrm{gm}$.) were sensitized with 1/10 c.c. of horse serum by intra. peritoneal injection. After fifteen days, two of them, used as controls, were given 1 c.c. of the same sensitizing serum directly into the heart; both died. Another guinea pig was given, intramuscularly, $15 \mathrm{mgm}$. of folic acid ten minutes before receiving the same dose of serum by intracardiac injection. This guinea pig also died of anaphylactic shock. Six others were given $30 \mathrm{mgm}$. of folic acid by intraperitoneal injection (to accelerate absorption), and the same serum treatment fifteon minutes later. All of them survived. Finally, the last guinea pig wos given $15 \mathrm{mgm}$. of folic acid intraperitoneally and the same serum treatment after fifteen minutes. This one survived, too, but showed slight symptoms of shock.

These experiments show clearly a protective action of folic acid against the anaphylactic shock in guinea pigs. This action reveals itself after a certain time and using very large doses of folic acid. Thus it may be supposed that folic acid acts in macrocytic anæmia as an anti-anaphylactic and thus antihistaminic. Assuming, as a pure hypothesis, that macrocytic anæmia may be due to an anaphylactic blockage of bone-marrow, especially as regards erythropoiesis, the successful results obtained with small doses of folic acid might be explained by a particular anti-anaphylactic action of this substance specific for normal erythropoiesis cells.

It may be remembered that agranulocytosis of Werner - Schultz, almost universally considered as a 